\title{
Critical Digital Pedagogy and Innovative Model, Revisiting Plato and Kant: An Environmental Approach to Teaching in the Digital Era
}

\author{
Lucy Lunevich \\ School of Engineering, RMIT University, Melbourne, Australia \\ Email: lucy.lunevich@rmit.edu.au, llunevich@yahoo.co.nz
}

How to cite this paper: Lunevich, L. (2021). Critical Digital Pedagogy and Innovative Model, Revisiting Plato and Kant: An Environmental Approach to Teaching in the Digital Era. Creative Education, 12, 20112024.

https://doi.org/10.4236/ce.2021.129154

Received: July 29, 2021

Accepted: September 4, 2021

Published: September 7, 2021

Copyright $\odot 2021$ by author(s) and Scientific Research Publishing Inc. This work is licensed under the Creative Commons Attribution International License (CC BY 4.0).

http://creativecommons.org/licenses/by/4.0/

\section{(c) (i) Open Access}

\begin{abstract}
Like any kind of innovation, innovation in pedagogy specifically critical digital pedagogy takes new ideas and practices and brings them together in new ways to solve problems which presently do not have adequate solutions. Developing new pedagogical models, however, involves both the identification of problems and testing the old practices and the suggestion of novel practices. The present research evaluates various themes of critical pedagogy, suggests an innovative model, and focuses on intentions when evaluating pedagogies rather than assuming they all have the same purpose. It suggests a critical digital pedagogy framework for the multitude of decisions teachers make to assess their own teaching and the digital literacy of their students.
\end{abstract}

\section{Keywords}

Critical Digital Pedagogy, Learning Styles, Pedagogy, Social Pedagogy, Innovative Model

\section{Introduction}

The full power of pedagogy and pedagogical innovations can only be evaluated by considering all the things the pedagogies are trying to achieve. Theories of education consider the interactions between students and teachers, between the state and the educational system, and between universities and the economic, technological, and social development of society. Therefore, critical digital pedagogy must look beyond the internal relationships of the teacher and students, as well as their social environment. It must also be open to innovations, interfe- 
rences, and dynamic changes. This would thereby form subject competencies and design the formation of social, communicative, and life competencies (Smith \& Jeffry, 2013; Smith, 2021; Volov, 2007). Teaching and learning processes have several components: purpose and objectives, content, methods, teaching tools, learning forms, and results. To achieve teaching and learning objectives, all areas of critical pedagogy must be considered in the context of new environments and social and technological changes (Lunevich, 2021; Myamesheva, 2015). In this research work, a new concept of critical digital pedagogy is suggested based on research observations, personal communications, and recent conference presentations. Recent developments in pedagogy have been consolidated as an innovative model for higher education, presented in Figure 1.

We live in an age of information: communication technologies and the data economy are the primary tools of production that contribute to enhancing the social positions of students (Rogers, 2013; Smith \& Lovat, 2003). With online and blended learning and teaching practices becoming more common, the ratio of students per teacher can reach into the hundreds (Smith \& Jeffry, 2013; Smith, 2021; Siemens, 2021). Critical digital pedagogy requires the development of innovations in education and pedagogy, and a new approach to teaching and learning (Rosen \& Smale, 2015; Lunevich, 2021; Rogers, 2013). Although technical know-how is one aspect of digital literacy, curriculum documents tend to

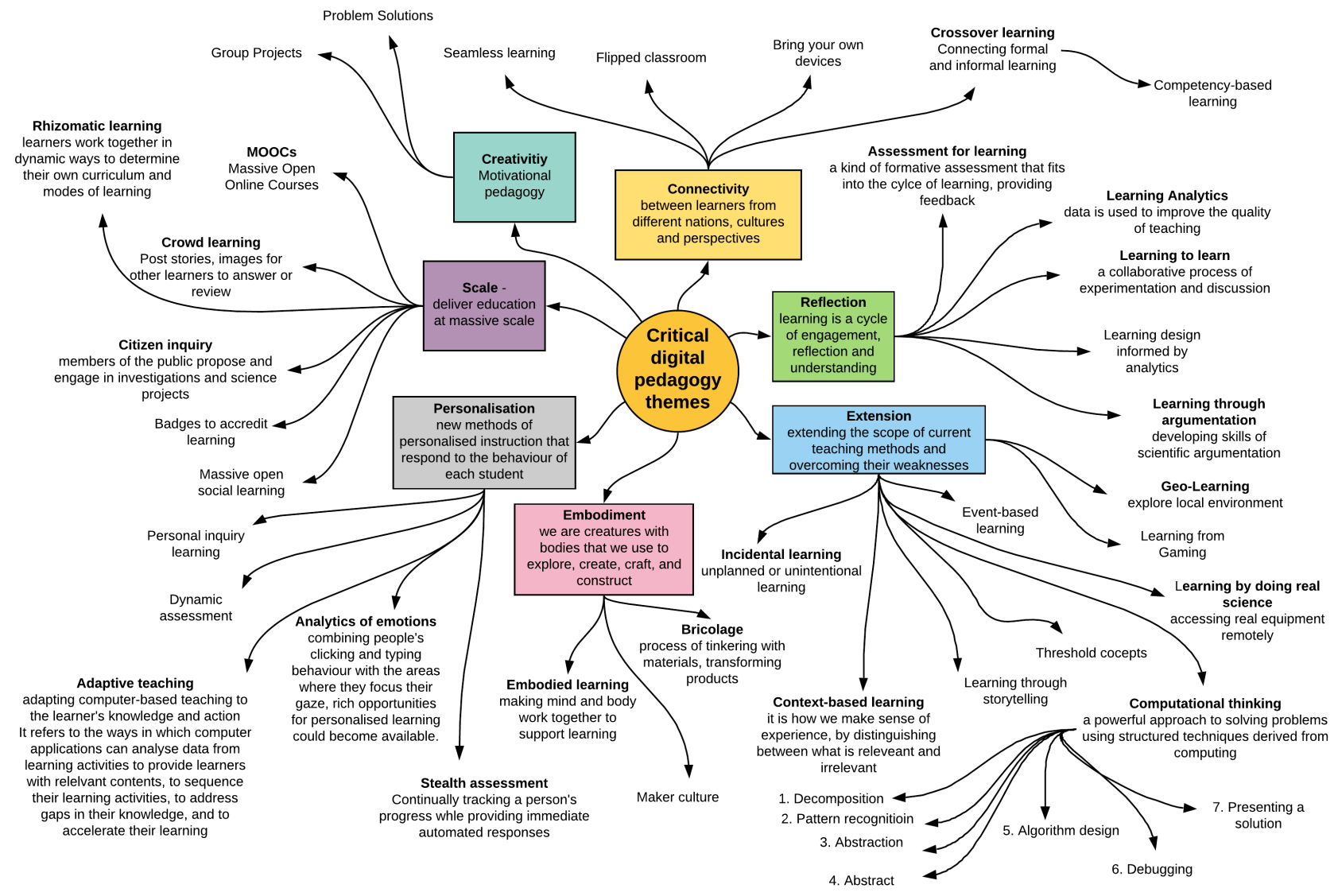

Figure 1. Critical digital pedagogy themes: the Lunevich model. 
overlook social, cultural, and ethical issues related to learning with technology (Hobbs, 2010; Hadziristic, 2017). However, they do examine local and global responsibilities and professional practice (Vasquez, 2013; Volov, 2007). According to Hadristic (2017) and Smith \& Jeffry (2013), the main challenges educators face are insufficient opportunities for professional development to build digital pedagogical competencies and update curricula to create effective pedagogies (Hadziristic, 2017; Smith \& Jeffry, 2013). The professional development of year12 teachers in Canada has focused on developing digital skills and competencies and has consequently neglected to engage with the cultural and social contexts of technology use and integration (Haight et al., 2014; Howe, 2009). The lack of analyses of knowledge production and power relations in technology often results in educational practices that inadvertently repeat historical patterns of injustice and inequality (Haight et al., 2014; Kukushkina, 2002; MacNeill, 2003). Critical pedagogy should stress the mastery of not only technical skills but also critical thought (Haight et al., 2014). According to Hobbs and others, digital competencies must move from merely acquiring functional skills to solving community, regional, or national issues (Hobbs, 2010; Helsper, 2010; Mynbayeva \& Sadvakasova, 2007; Mynbayeva \& Anarbek, 2016).

Baround (2020) have pointed out that digital technologies should be considered not only as tools for meaning-making, but also as digital texts and platforms for literacy practices (Baroud, 2020; Balasanyan, 2019). This shift would encourage teachers to consider integrating critical digital literacies into curricula rather than treating them as an optional topic to be addressed. It is believed that such a paradigm shift would encourage educators to consider thinking critically, ethically, and responsibly, and design literacy-learning opportunities that respond to institutional, social, and economic contexts and requirements (Lunevich, 2021; Balasanyan, 2019; Howe, 2009; Hobbs, 2010).

\section{Re-Emerging Pedagogy}

Smith and Smith assert that pedagogy is wrongly seen as the "art and science of teaching" (Smith, 2012; Smith \& Jeffry, 2013). Pedagogy also involves joining with others to bring relationships to life (animation), being concerned about one's own and other's needs and well-being, taking practical steps to help (caring), and encouraging reflection, commitment, and change (education) (Kukushkina, 2002; Kant, 1900). Smith (2021) and PLATÃO (1988) added that education is a deliberate process of drawing out learning (Latin: educere) and of encouraging and giving time for discovery (Smith, 2021; PLATÃO, 1988). It is an intentional act, a process of inviting truth and possibility, and is "based on certain values and commitments such as respect for others and for truth" (Smith, 2021). According to Smith \& Lovat (2003), Smith (2012), Cope (2021) and Freire (2005), pedagogy has many different facets, including pedagogy of the oppressed, critical pedagogy, digital pedagogy, and social pedagogy (Lunevich, 2021).

Four main competence areas have also been identified: pedagogical, technolo- 
gical, collaborative, and creative (Lunevich, 2021; Kukushkina, 2002). According to Smith (2021), this "refers to competencies involved in making pedagogical choices throughout the process of teaching and learning" in a game-based context (Smith \& Jeffry, 2013). Kukushkina (2002) also states that "pedagogy involves conveying knowledge and skills in ways that students can understand, remember," and apply, regardless of which learning style the learner has (Kukushkina, 2002). Twenty-first century pedagogy aims to develop the skills and knowledge students need to succeed in work, life, and citizenship. Twenty-first century skills can be applied in all subject areas and all educational, career, and civic settings throughout a student's life (Mynbayeva \& Anarbek, 2016; Mynbayeva, 2012, 2018).

Lunevich (2021) pointed out that pedagogy is about connecting a learner's mind and heart (Lunevich, 2021). According to MacNeill it is also a matter of grace and wholeness, wherein students can engage fully with their innate gifts and strengths (MacNeill, 2003). As Pestalozzi and others affirmed, education is rooted in human nature; it is a matter of "head, hand, and heart" (Pestalozzi, 2010; Bruhlmeier, 2010; Colligan, 2020). In life, each person develops their own sense of identity, meaning, and purpose "through connections to the community, to the natural world, and to spiritual values such as compassion and peace" (Kant, 1900; Kukushkina, 2002). Pedagogy is also conceptualized as a process of "accompanying learners; caring for and about them; and bringing learning into life" (Bordovskaya, 2000; Kupsevich, 1986). Plato and others made a distinction between education (Latin: educatio) and teaching (Latin: instructio). "Education means shaping the development of character with a view to the improvement of man" (PLATÃO, 1980a, 1988) while "[t]eaching represents the world, conveys fresh knowledge, develops existing aptitudes and imparts useful skills...” (Podlasy, 1996; Plato, 1925). Teaching is concerned not just with "knowing about" things, but also with changing oneself and the world one lives in (Rogers, 2013; Lunevich, 2021; Myamesheva, 2015).

Within ancient Greek society, there was a substantial distinction between the activities of pedagogues (paidagögus) and subject teachers (didáskalos) (Smith \& Jeffry, 2013). Plato talks about pedagogues as "men who by age and experience are qualified to serve as both leaders (hëgemonas) and custodians (paidagögous [sic])" of children (PLATÃO, 1980b). Their roles varied, but two elements were common between them. "The first was to be an accompanist or companioncarrying books and bags and ensuring their wards were safe" (PLATÃO, 1980a). The second and more fundamental task was to help boys learn what it was to be men. They accomplished this by a combination of example, conversation, and discipline. Pedagogues were moral guides who were to be obeyed (Bernstein, 1990; Kharbach, 2021). Employing a pedagogue was a custom that went far beyond Greek society: well-to-do Romans and some Jews also placed their children in the care and oversight of trusted servants (Smith, 2021). The relation of the pedagogue to the child is a fascinating one. It brings new meaning to notion 
of the "pedagogy of the oppressed"-the education of the privileged by the oppressed (Freire, 2005). It was a matter that, according to Plato, did not go unnoticed by Socrates (Plato, 1925). In a conversation between Socrates and a young boy, Lysis, Socrates asked, “Someone controls you?" Lysis replied, "Yes, he is my tutor [or pedagogue] here." "Is he a slave?" Socrates queried. "Why, certainly; he belongs to us," responded Lysis, to which Socrates mused, "What a strange thing, I exclaimed; a free person controlled by a slave!” (Plato, 1925, quoted by Smith, 2006).

The distinction between teachers and pedagogues, instruction and guidance, and education for work or life was a recurring feature of discussions around education for many centuries. It was still around when Immanuel Kant (1900) explored education (Kant, 1900). In On Pedagogy (Über Pädagogik), first published in 1803, he wrote that culture is positive, consisting of instruction and guidance (and thus forming part of education) (Kant, 1900). Guidance means directing the pupil in putting into practice what he has been taught. This illustrates the difference between a private teacher who merely instructs, and a tutor or governor who guides and directs his pupil. The former trains the student for a job only; the latter trains the student for life (Kant, 1900; Smith, 2021).

One of the important landmarks in pedagogical research was the publication of John Amos Comenius's book The Great Didactic [Didactica Magna], first published in Czech in 1648, Latin in 1657, and English in 1896). For Comenius, the fundamental aims of education generated the basic principle of Didactica Magna, omnis, omnia, omnino-to teach everything to everybody thoroughly, in the best possible way (Smith, 2021). Comenius believed that every human being should strive for perfection in all that is fundamental for life and do this as thoroughly as possible (Smith, 2012; Lunevich, 2021). According to Colligan (2020) every person must strive to become 1) a rational being, 2) a person who can rule nature and their own self, and 3) a being mirroring the creator (Colligan, 2020; Bordovskaya, 2000). He developed sets of rules for teaching and laid out basic principles. His fundamental conclusions, according to Colligan (2020), remain valid: 1) teaching must be in accordance with the student's stage of development; 2) all learning happens through the senses; 3 ) one should teach in order from the specific to the general, from what is easy to what is more difficult, from what is known to what is unknown; 4) teaching should not cover too many subjects or themes at the same time; and 5) teaching should proceed slowly and systematically. Nature makes no jumps (Colligan 2020). Later in this paper, this concept is tested.

Following Kant and Comenius, another significant turning point in thinking about teaching came through the growing influence of one of Kant's successors as the Chair of Philosophy at the University of Königsberg, Johann Friedrich Herbart (1776-1841) (Freire, 2005). Like practical and theoretical educationists before him, Herbart distinguished between education (Latin: educatio) and teaching (Latin: instructio). "Education," according to Hebart, meant shaping 
the development of a student's character with a view to their personal improvement, while "teaching" represented the world, conveyed fresh knowledge, developed existing aptitudes, and imparted useful skills (Freire, 2005). Before Herbart, it was unusual to combine the concepts of "education" and "teaching". Consequently, questions pertaining to education and teaching were initially pursued independently. In his educational theory, Herbart took the bold step of subordinating the concept of teaching to that of education. As he saw it, external influences, such as the punishment or shaming of pupils, were not the most important instruments of education (Freire, 2005; Herbet, 2013). On the contrary, appropriate teaching was the only sure means of promoting education that was bound to prove successful.

In Aristotle's terms, pedagogy comprises a leading idea (eidos), what we are calling haltung or disposition (phronesis-a moral disposition to act truly and rightly), with dialogue and learning (interaction) and action (praxis-informed, committed action) (Smith \& Lovat, 2003). In the following summary, many of the elements that have been explored here are present (Smith \& Lovat, 2003; Smith, 2012). To this, we must add what Aristotle discusses as hexis-a readiness to sense and know. This is a state of being, or what talks about as an "active condition". It allows us to take a step forward, both in terms of the processes discussed above and in what we might seek to do when working with learners and participants. Such qualities are conceptually at the core of the haltung and the processes of pedagogues and informal educators.

Within critical pedagogy, there is a strong emphasis upon being in touch with one's feelings, attending to one's intuition, and seeking evidence to confirm or question what one might be sensing. A further element is also present: a concern to not take things for granted or simply accept them at face value. Figure 1 shows several themes of the critical digital pedagogy and innovative model suggested.

The research and history of pedagogy from Plato and Kant to the modern day necessitates that critical pedagogy must consider all of these different themes of creativity simultaneously: connectivity, reflection, extension, embodiment, personalisation, and scale. This approach helps create learning content and learning environments that consider all learning styles and learners' various social and cultural backgrounds. Kant in his work "The Critique of Pure Reason. The Critique of Practical Reason and Other Ethical Treatises and Critique of Judgement" said that all know begins with experience there can be no doubt (Adler, 2007). He continued it is, therefore, a question which requires close investigation, and not be answered at first sight, whether there exists a knowledge altogether independent of experience, and even of all sensuous impressions? (Adler, 2007).

\section{Critical Digital Pedagogy Innovative Model}

Research indicates that the critical features of a 21 st-century education include personalised learning; equity, diversity, and inclusivity; learning through doing; 
the changed role of the teacher; community relationships; technology; and teacher professionalization (Smith \& Jeffry, 2013; Smith, 2021; Rogers, 2013; Pestalozzi, 2010). According to Smith (2021), teacher "preparation and professional development should be reworked to incorporate training in teaching key competencies." (Smith, 2021). The 21st-century teacher must know how to provide technologically-supported learning opportunities for students and understand how technology can support learning (Smith, 2021; Mynbayeva, 2018). Specifically, the five steps pertaining to this are preparation, presentation, association, generalization, and application (Smith, 2021). This "suggests that pedagogy relates to having assumptions as an educator and a specific set of abilities with a deliberate end goal in mind" (Smith, 2021; Soldatova, 2015; So, 2013).

However, critical digital pedagogy is concerned with engaging students in all learning styles, assuming that any individual has a minimum of two or three learning styles (Smith, 2021). These styles include seven types that must be considered when courses are offered online and in a blended mode (face-to-face and online) (Table 1). The summary of data presented in Table 1 is based on the observation research, conducted with 182 master of engineering students over the 12-month period, two academic semesters. Students were involved in this research in three ways. Over 120 students completed a one-page questionnaire which asked about their preferred learning styles. Students who were not able to

Table 1. Learning styles.

\begin{tabular}{|c|c|}
\hline Learning style & $\begin{array}{l}\text { Preferred learning } \\
\text { environments }\end{array}$ \\
\hline Visual (spatial) learner: prefers learning by observing things & Face-to-face, online \\
\hline Aural (auditory) learner: prefers to learn face-to-face in class & $\begin{array}{l}\text { Face-to-face, classroom, } \\
\text { workshops }\end{array}$ \\
\hline $\begin{array}{l}\text { Verbal (linguistic) learner: prefers a style that involves both the written } \\
\text { and spoken word }\end{array}$ & Face-to-face, online \\
\hline $\begin{array}{l}\text { Physical (kinesthetic) learner: often referred to as "learning with the } \\
\text { hands" or physical learning }\end{array}$ & $\begin{array}{l}\text { Face-to-face, classroom, } \\
\text { workshops }\end{array}$ \\
\hline Logical-mathematical learning style: able to reason, solve problems, and & \\
\hline $\begin{array}{l}\text { learn using numbers, abstract visual information, and analysis of } \\
\text { cause-and-effect relations }\end{array}$ & Face-to-face, online \\
\hline $\begin{array}{l}\text { Interpersonal learner: learns best through communication with others, } \\
\text { whether verbal or nonverbal. Interpersonal learners love being around } \\
\text { people and working in groups or teams and overall thrives through social } \\
\text { interactions. They are often seen as social butterflies because they like } \\
\text { spending much of their time with others. Interpersonal learners love } \\
\text { sharing their knowledge with others but also love listening to their peers. }\end{array}$ & $\begin{array}{l}\text { Face-to-face, classroom, } \\
\text { workshops }\end{array}$ \\
\hline $\begin{array}{l}\text { Solitary learner: also known as an intrapersonal learner. Prefers learning } \\
\text { on their own. They are self-motivated, enjoy working independently, and } \\
\text { learn best when working alone. Solitary learners spend much time in } \\
\text { self-reflection and enjoy working on themselves. They also favour a quiet } \\
\text { environment in both their personal and academic lives. }\end{array}$ & $\begin{array}{l}\text { Online, blended learning } \\
\text { environment }\end{array}$ \\
\hline
\end{tabular}


answer to the questions about their preferred learning styles, were given other practical exercises. Each practical exercise was presenting one of the learning style listed in Table 1.

Most learners have several learning styles, rather than simply one or two (Taubayeva \& Laktionova, 2001; Soldatova, 2016; Sitarov, 2008). Therefore, a challenge for critical digital pedagogy is to consider all learners' learning styles and design courses, programs, and learning environments and adopt engagement strategies that include all learners (Mynbayeva, 2012; Lunevich, 2021; Smith, 2021). Critical digital pedagogy is an emerging discipline within pedagogy which seeks to study and use contemporary digital technologies in teaching and learning, although this might not always consider all learning styles and learners' requirements to progress well. Critical digital pedagogy may be applied to online, hybrid, and face-to-face learning environments.

Critical digital pedagogical skills for teachers "thus include the capacity to plan, initiate, lead, and develop education and teaching with the departure point in both general and subject-specific knowledge of student learning" (Hadziristic, 2017; Hegenan \& Olson, 2004; English, 2015). Critical digital pedagogical skills also include assessing students' digital skills and learning styles, and then connecting the teaching to research on the subject of interest (Rogers, 2013; Alexander, 2008). Critical pedagogy is the relation between learning techniques and culture and social environment need to be considered in teaching (MacNeill, 2003, Mynbayeva \& Sadvakasova, 2007). It is determined based on an educator's beliefs about how learning takes place. Pedagogy requires meaningful classroom interactions between educators and learners (Lewin \& Lundie, 2016; Lunevich, 2021; Mynbayeva \& Anarbek, 2016). The goal is to help students build on prior learning and develop skills and attitudes regardless of whether they are in class or online. Critical digital pedagogy must be culturally relevant: it must focus on multiple aspects of student achievement and support students to uphold their cultural identities (Kukushkina, 2002; Kupsevich, 1986). Culturally relevant pedagogy also calls for students to develop critical perspectives that challenge societal inequalities (Lunevich, 2021; Smith, 2021). Furthermore, the five principles of pedagogy are motivation, exposition, direction of activity, criticism, and inviting imitation will need to be considered in learning design (Soldatova, 2016; Mynbayeva \& Anarbek, 2016; Rogers, 2013).

\section{Recent Data on Digital Learning}

In the paper "Critical pedagogies in the neoliberal university: What happens when they go digital?", Smith and Jeffry (2013) discussed the "successful" online education performance (Smith \& Jeffry, 2013). As a technology of reform, online education creates intense structural change within postsecondary institutions and reconstitutes what it means to teach critically and engage learners in multiple different ways (Mynbayeva \& Anarbek, 2016; Mynbayeva, 2018; Mukazhanova, 2013; Lunevich, 2021). Although it can be argued that much of academic 
labour has always been hidden and unrecognized, the introduction of online teaching practices substantially increases invisible work by approximately $80 \%$, according to our research and research conducted by others over the past two years. Online teaching entails an intensification of what is expected of educators within a space of work without boundaries (Smith \& Jeffry, 2013; Lunevich, 2021). Overwhelming reports from universities and academics describe online teaching as a constant struggle—night and day, seven days a week—to stay on top of responses to emails and monitor students' posts on course sites. Far more than a problem of poor boundaries, these work practices must be seen alongside rising pressures to be "always on the job" (Smith \& Jeffry, 2013). As Hobbs (2010) found, online technology can monitor faculty availability, activities, and responsiveness to student demands (Hobbs, 2010). Some warn that these heightened surveillance measures could result in loss of autonomy and increased scrutiny, risking the creation of conditions leading to a rise in self-censorship and potential loss of academic freedom (Smith \& Jeffry, 2013). Just as surveillance mechanisms transform the relationship between educators and their workplaces, the introduction of commercialized instructional products promises to radically alter how they engage with students. Online tracking of student learning should provide an instructor with the knowledge of how well they integrate unsettling course content, such as theorizations of antiracism and the online effects of colonialism. The result is that students are treated not as learners but as users of software data collection technology (Smith \& Jeffry, 2013). Smith and Jeffrey pointed out that if education is to be efficient, then it simply must be capable of being measured (Smith \& Jeffry, 2013). However, critical digital pedagogies do not lend themselves readily to easy measurement in this way.

How could this spatial shift from critical pedagogies to critical digital pedagogies offer better values to learners and educators? What should an innovative model look like? To respond to these questions, we must revisit Plato and Kant. Plato said that "knowledge is the food of the soul" and "writing is the geometry of the soul"; however, "knowledge becomes evil if the aim be not virtuous". This is the ideal of education expressed by the concepts of truth, goodness, and beauty (PLATÃO, 1988).

In the environmental approach, information and energy become important categories. During lessons, there is a dynamic exchange of information, knowledge, and energy between teacher and student. According to Mukazhanova, the value of "love" is understood as an energy exchange between people; for example, mother and child (Mukazhanova, 2013). Positive attitudes in study and occupation, such as the positive energy generated by the teacher, set a special positive atmosphere for learners (Mynbayeva \& Sadvakasova, 2007; Mynbayeva \& Anarbek, 2016; Mynbayeva, 2018). Plato stressed the importance of "platonic love" or "spiritual communication between teacher and student" (Plato, 1925). Therefore, in critical digital pedagogy, positive motivating methods should be used in order to create an environment that is positive for learning. This envi- 
ronment becomes saturated with both information and positive energy (Lunevich, 2021). The teacher simultaneously teaches and learns from students (Mynbayeva, 2012; Smith, 2021). As the ratio of students to teachers reaches hundreds, there are tens of thousands of instances of digital technology being used for teaching, critical digital pedagogy calls for innovations in education, pedagogical innovations, and a new approach to teaching and learning. As Mynbayeva et al. (2018) pointed out, social and digital participation is a "new concept of the practice of informal, socially-digital mediated participation" (Sweeney, 2014). According to Soldatova's and Zotova's research, changes have occurred in the digital generation's memory, attention, and thinking (Soldatova, 2015, 2016). The average length of time for which students can concentrate, compared to that of 10 to 15 years ago, decreased 10 times from 120 minutes to 12 minutes (Soldatova, 2015, 2016). According to Mynbayeva et al. (2018), "a new phenomenon is clip thinking". It is based on the fragmentary processing of visual images, rather than "on logic and text associations" (Soldatova, 2015, 2016). Digital technologies have changed our way of life and ways of communication, as well as our thinking, feeling, and connecting to others. They also provide channels to influence other people, social skills, and social behaviour (Sweeney, 2014; Smith \& Jeffry, 2013).

There is something important in the dynamics of teaching and learning needs to be carried forward from old critical pedagogy to critical digital pedagogy; this is the "spiritual communication between teacher and student" (Lunevich, 2021; PLATÃO, 1980b). This aspect creates new requirements for teachers and their professional development. Teachers must learn new information and new technologies quickly, and a creative approach to teaching and connecting the "mind and hearts" of students is an essential aspect of this new social environment (Lunevich, 2021; Mukazhanova, 2013; Podlasy, 1996; Smith \& Jeffry, 2013). In this context, teachers are responsible for encouraging, facilitating, directing, and monitoring the progress of online interactions among students during and between classes. This is knowledge obtained through interaction with the network community. Such a process of obtaining knowledge is characteristic of an already prepared or adult person who can critically evaluate, analyse, choose, and construct knowledge.

In education, and particularly in higher education, learning has shifted from acquiring knowledge and skills to forming competencies and practical applications of that knowledge and value for money. As a result, critical digital pedagogy should integrate several methods of communication and types of instruction. It is obvious that critical digital pedagogy calls for the development of innovations in education or new pedagogical models. However, innovation is a phenomenon that carries the essence, methods, techniques, technologies, and content of the new (Lewin \& Lundie, 2016). According to Pedagogy of the Twenty-First Century: Innovative Teaching Methods, "innovative teaching methods involve new ways of interacting between teacher and student and a certain in- 
novation in practical activity in the process of mastering educational material" (Rosen \& Smale, 2015; Balasanyan, 2019). The key to critical digital pedagogy is that the teacher simultaneously teaches and learns from the students.

\section{Conclusion}

The methodology of teaching is built on a personal-oriented or student-centred approach to learning. The approaches it synthesizes can be described as synergetic, systematic, competent, dialogical, activity-oriented, culturological, informative, technological, and environmental. Volov (2007) has recommended the following teaching strategies: experimental learning, storytelling, values education, enquiry learning, and community problem-solving. Creative and innovative teaching approaches are becoming increasingly necessary: the more exciting and diverse they are, the better. These teaching strategies also shape the experience of solving nonstandard problems, promote in-depth training, and aid in the steady assimilation of the technology of practical activity. A good teacher constantly improves their own pedagogical skills and selects and develops new methods and technologies of teaching. A good university constantly monitors the quality of its education and the value it delivers to learners and the economy. Universities currently tend to have their own business models which are supposed to deliver unique values to the community, connect with the external environment, and find various funding opportunities.

\section{Acknowledgements}

I would like to express my deep gratitude to Mr Nikolai Lunevich, my dear friend, husband for his patient guidance, enthusiastic encouragement and useful critiques of this research work, which becomes the publication.

\section{Conflicts of Interest}

The author declares no conflicts of interest regarding the publication of this paper.

\section{References}

Adler, M. J. (2007). Great Books of Western World, Immanual Kant (Vol. 39). Encyclopedia Britannica, Inc.

Alexander, R. (2008). Essays on Pedagogy. Routledge.

Balasanyan, B. (2019). Lessons from the History of Pedagogical Methods for Culturally Responsive Teaching and Learning. In Education Systems around THE World (pp. 9-23). IntechOpen. https://doi.org/10.5772/intechopen.90695

Baroud, J. D. (2020). A Collaborative Self Study of Critical Digital Pedagogy in Teacher Education. Studying Teacher Education, 16, 164-182.

https://doi.org/10.1080/17425964.2020.1739639

Bernstein, B. (1990). The Structuring of Pedagogical Discourse. Class, Codes and Control (Vol. 4). Routledge.

Bordovskaya, N. R. (2000). Pedagogy: Textbook for Students of Pedagogic Universities. 
Publishing House Piter.

Bruhlmeier, A. (2010). Head, Heart and Hand. Education in the Spirit of Pestalozzi. Sophia Books.

Colligan, C. A. (2020). Notes from the Field: Student Perspectives on Digital Pedagogy. Digital Studies. https://doi.org/10.16995/dscn.382

Cope, B. K. (2021, June 10). Ubiquitous Learning: An Agenda for Educational Transformation.

https://www.researchgate.net/publication/228347819 Ubiquitous learning An agenda for educational transformation/link/00b7d51b7a236ad703000000/download

English, L. (2015). STEM: Challenges and Opportunities for Mathematics Education. Proceedings of the 39th Meeting of the International Group for the Psychology of Mathematics Education, Vol. 1, 4-18.

Freire, P. (2005). Pedagogy of the Oppressed. Continuum.

Hadziristic, T. (2017). The State of Digital Literacy in Canada: A Literature Review. Brookfield Institute for Innovation and Entrepreneurship.

https://brookfieldinstitute.ca/wp-content/uploads/BrookfieldInstitute State-of-DigitalLiteracy-in-Canada Literature WorkingPaper.pdf

Haight, M., Quan-Haase, A., \& Corbett, B. A. (2014). Revisiting Digital Divide in Canada: The Impact of Demographic Factors on Access to the Internet, Level of Online Activity, and Social Networking Site Usage. Information, Communication and Society, 17, 503-519. https://doi.org/10.1080/1369118X.2014.891633

Hegenan, B., \& Olson, M. (2004). The Theory of Learning. Publishing House Piter.

Helsper, E. A. (2010). Digital Natives: Where Is the Evidence? British Educational Research Journal, 36, 503-520. https://doi.org/10.1080/01411920902989227

Herbet, R. (2013). Dewey on Discountinuoty of Education. Cambridge University Press.

Hobbs, R. (2010). Digital and Media Literacy. A Plan of Action. The Aspen Institute.

Howe, N. S. (2009). Millennias Rising: The Next Great Generation. Vintage Books, Random House.

Kant, I. (1900). Kant on Education. http://files.libertyfund.org/files/356/0235 Bk.pdf

Kharbach, M. (2021, June 22). Educational Technology and Mobile Learning. https://www.educatorstechnology.com/2013/05/awesome-chart-on-pedagogy-vs-andra gogy.html

Kukushkina, V. (2002). Pedagogical Technologies: Teaching Aid for Students of Pedagogical Specialties. Publishing House Mart.

Kupsevich, C. (1986). Fundamentals of General Didactics. Vysshaya shkola.

Lewin, D, \& Lundie, D. (2016). Philosophies of Digital Pedagogy. Studies in Philosophy and Education, 35, 235-240. https://doi.org/10.1007/s11217-016-9514-7

Lunevich, L. (2021). Creativity in Teaching and Teaching for Creativity in Engineering and Science in Higher Education-Revisiting Vygotsky's The Psychology of Art. Research Journal of Creative Education, 12, 1445-1457.

https://doi.org/10.4236/ce.2021.127110

MacNeill, N. A. (2003). Pedagogical Leadership: Putting Professional Agency Back into Learning and Teaching. Curriculum and Leadership Education, 4, 84-98.

Mukazhanova, R. O. (2013). Self-Cognition Teaching Methods for Schools. Bobek NSPWC.

Myamesheva, G. (2015). The Virtue in the Modern Smart World. Pedagogical Science, 44, 152-156.

Mynbayeva, A. K., \& Sadvakasova, Z. M. (2007). Innovation Methods of Teaching, or 
How to Teach to Attract Students. DOIVA.

Mynbayeva, A. S. (2012). The Art of Teaching: Concepts and Innovative Methods of Teaching. Publishing House Kazakh University.

Mynbayeva, A. S. (2018). Pedagogy of the Twenty-First Century: Innovative Teaching Methods. In New Pedagogical Challenges in the 21st Century-Contributions of Research in Education (pp. 20-45). IntechOpen. https://doi.org/10.5772/intechopen.72341

Mynbayeva, A., \& Anarbek, N. (2016). Informatization of Education in Kazakhstan: New Challenges and Further Development of Scientific Schools. International Review of Management and Marketing, 6, 259-264.

Pestalozzi, J. (2010). Leonard and Gertrude. General Books.

PLATÃo (1980a). Ião. 2. ed. Tradução de Carlos Alberto Nunes. Edufpa.

PLATÃo (1980b). Hípias maior. 2. ed. Tradução de Carlos Alberto Nunes. Edufpa.

PLATÃO (1988). República. 2. ed. Tradução de Carlos Alberto Nunes. Edufpa.

Plato (1925). Lysis 208 C, trans WRM Lamd. Harvard University Press. https://doi.org/10.4159/DLCL.plato philosopher-lysis.1925

Podlasy, I. P. (1996). Pedagogy: Textbook for Students of Pedagogic Universities. Vlados.

Rogers, R. (2013). Cultivating Diversity through Critical Literacy in Teacher Education. In J. R. C. Kocnik (Ed.), Literacy Teacher Educators: Preparing Teachers for a Changing World (pp. 7-19). Sense. https://doi.org/10.1007/978-94-6209-200-6 2

Rosen, J. R., \& Smale, M. A. (2015). Open Digital Pedagogy-Critical Pedagogy (pp. 2-12). City University of New York (CUNY).

Siemens, G. (2021). Connectivism: Learning Theory or Pastime for the Self-Amused? https://www.semanticscholar.org/paper/Connectivism\%3A-Learning-Theory-or-Pasti me-of-the-Siemens/9b476f6d47e12f292e7bce21f10585f3ffcd7f16

Sitarov, V. (2008). Didaktika: Textbook. Publishing House Academy.

Smith, D. L., \& Lovat, T. J. (2003). Curriculum Action on Reflection. Cengage Learning.

Smith, K., \& Jeffry, D. (2013). Critical Pedagogy in the Neoliberal University: What Happens When They Go Digital? The Canadian Geographer, 57, 371-380. https://doi.org/10.1111/cag.12023

Smith, M. (2012, October 8). What Is Pedagogy? A Definition and Discussion. https://infed.org/mobi/what-is-pedagogy

Smith, M. (2021, June 15). infed.org: Education, Community-Building and Change. https://www.infed.org

So, W. W.-M. (2013). Connecting Mathematics in Primary Science Inquiry Projects. International Journal of Science and Mathematics Education, 11, 385-406. https://doi.org/10.1007/s10763-012-9342-3

Soldatova, G. O. (2015). Attitude to Privacy and Protection of Personal Data: Safety of Russian Children and Adolescents. National Psychological Journal, 3, 56-66. https://doi.org/10.11621/npj.2015.0306

Soldatova, G. R. (2016). "Digital Divide” and Intergenerational Relations of Children and Parents. Psikhologicheskiy zhurnal, 37, 44-554.

Sweeney, E. (2014, June 10). Digital Australia. https://digitalaustralia.ey.com/?utm content=buffer8ab23\&utm medium=social\&utm source=twitter.com\&utm campaign=buffer

Taubayeva, Sh. T., \& Laktionova, S. N. (2001). Pedagogical Innovation as a Theory and 
Practice of Innovations in the Education System. Gylym.

Vasquez, M. F. (2013). Technology and Critical Literacy in Early Childhood. Routledge. https://doi.org/10.4324/9780203108185

Volov, V. (2007). Innovative Principles of Education System. Pedagogy, 7, 108-114. 